\title{
Chemical Composition of Seeds of Two Endemic Lathyrus L. Species from Turkey
}

\author{
Yasin ARSLAN \\ Department of Nanoscience and Nanotechnology, Faculty of Arts and Science, \\ Mehmet Akif Ersoy University, Burdur, Turkey. \\ E-mail: yasinarslan80@yahoo.com
}

Diğdem TRAK

Department of Chemistry, Faculty of Arts and Science,

Mehmet Akif Ersoy University, Burdur, Turkey.

E-mail: digdemtrak@gmail.com

Bekir YILDIRIM

Department of Plant and Animal Production, Tefenni Vocational School,

Mehmet Akif Ersoy University, Burdur, Turkey.

E-mail: bytr33@yahoo.com

Hasan GENÇ (Corresponding author)

Department of Science Education, Faculty of Education,

Mehmet Akif Ersoy University, Burdur, Turkey.

E-mail: hagetr@yahoo.com

\section{Erdal KENDÜZLER}

Department of Chemistry, Faculty of Arts and Science,

Mehmet Akif Ersoy University, Burdur, Turkey.

E-mail: kenduzler@mehmetakif.edu.tr 
Received: April 1, 2018 Accepted: April 18, 2018

doi:10.5296/jbls.v9i2.12920ＵRL: https://doi.org/10.5296/jbls.v9i2.12920

\begin{abstract}
Genus Lathyrus L. belonging to Fabaceae (Leguminosae) family consisted of 77 taxa at the species, subspecies, and variety level at Turkey and 25 of that were known as endemic. Lathyrus egirdiricus H.Genc \& A.Sahin and Lathyrus tefennicus H. Genç \& A. Şahin were endemic species and described at the date of 2008 and 2011, respectively. The seeds of Lathyrus tefennicus and Lathyrus egirdiricus were collected in Tefenni of Burdur province and Eğirdir of Isparta province in May of 2016 at Turkey. The concentration of $\mathrm{Cd}, \mathrm{Cr}, \mathrm{Ni}$, $\mathrm{Cu}, \mathrm{Mn}, \mathrm{Zn}, \mathrm{Fe}, \mathrm{Ca}, \mathrm{Mg}, \mathrm{Na}$ and $\mathrm{K}$ in the Lathyrus tefennicus and Lathyrus egirdiricus seeds were determined by Atomic Absorption Spectrometry. A microwave oven was used for the sample digestion. The accuracy of proposed method was confirmed by the analysis of the certified reference material (EnviroMAT Contaminated Soil). All results were given at 95\% of confidence level. The presence of different concentrations of elements in the seeds of both species strengthens the belief that this data can be used in plant taxonomy.
\end{abstract}

Keywords: Chemical composition, Elements, Lathyrus egirdiricus, Lathyrus tefennicus, Turkey

\title{
1. Introduction
}

Lathyrus L. belongs to the tribe Vicieae within the Fabaceae (Leguminosae). It contains more than 200 taxa and has an almost worldwide distribution (Allkin et al., 1986). The main centers of diversity of Lathyrus were the Mediterranean region, Asia Minor and North America, as well as South America and East Africa (Klamt \& Schifino-Wittmann, 2000). Tutin et al. (1968) reported that 54 species of Flora Europaea were known. Davis (1970) stated that the genus was represented as 67 taxa at the species, subspecies, and variety level in Flora of Turkey. However, the number of taxa at Turkey was increased to 77 and 25 of that were known as endemic (Davis et al., 1988; Güner et al., 2000; Genç \& Şahin, 2008; Genç, 2009; Genç \& Şahin, 2011; Güneş \& Çırpıc1, 2012; Güneş, 2014). Lathyrus L. was important owing to economically and nutritionally. In general, L. sativus L., L. hirsutus L., L. cicera L., L. ochrus (L.) DC. and L. sylvestris L. were cultivated for forage and human food. These species were highly nutritious and favorite food for domestic animals (Yamamoto et al., 1984). It was stated that Lathyrus sativus, L. cicera, L. ochrus and L. clymenum L. were cultivated at Turkey (Genç \& Şahin, 2001).

If the atomic number and mass of elements were bigger than 20 and $5 \mathrm{~g} / \mathrm{cm}^{3}$, respectively, they were called as heavy metals (Lajayer et al., 2017). The metal pollutants in the environment caused hazard effect for all living organisms. In last decades, different industrial activities such as battery and paint manufacture, fertilizer usage and wastes have caused to metal contaminations in the soil, water and air (Amari et al., 2017) causing the accumulation of them in the plants (Filipiak-Szok et al., 2015). 


\section{Mll Macrothink}

Journal of Biology and Life Science ISSN 2157-6076 2018, Vol. 9, No. 2

The heavy metals were transferred from the soil to plant and following accumulated in the seeds, cereals, fruits, roots, stalks and leaves. To investigate the physiological activity of the plant, the concentrations of $\mathrm{Cr}, \mathrm{Mn}, \mathrm{Mo}, \mathrm{Zn}, \mathrm{Fe}, \mathrm{Co}, \mathrm{Cu}, \mathrm{Al}, \mathrm{Ni}$ should be determined (Filipiak-Szok et al., 2015; Heredia et al., 1016). When the plant included excessive or low amount of these metals, it caused to a negative effect for the plant health (Heredia et al., 2016). Because some metals such as $\mathrm{Pb}, \mathrm{Ni}$, and $\mathrm{Co}$ hinder to ecesis as well as make prohibition effects on the plants (Mohamed et al., 2017), determination of metals in the plants were important.

There were some analytical methods such as flame atomic absorption spectrometry (FAAS), graphite furnace atomic absorption spectrometry (GFAAS), inductively coupled plasma optical emission spectrometry (ICPOES), and inductively coupled plasma mass spectrometry (ICPMS) were used for the determination of metals in any samples (Santos Júnior et al., 2017). Among them, FAAS was frequently used because of its some advantages such as more speed, lower cost and higher accessibility (Elik et al., 2017).

In this study, determinations of 11 different metals such as $\mathrm{Cd}, \mathrm{Cr}, \mathrm{Ni}, \mathrm{Cu}, \mathrm{Mn}, \mathrm{Zn}, \mathrm{Fe}, \mathrm{Ca}$, $\mathrm{Mg}, \mathrm{Na}$ and $\mathrm{K}$ in the both Lathyrus tefennicus and Lathyrus egirdiricus seeds were performed by FAAS method. The microwave method was used to digest seeds because of its rapid and repeatable properties (Tüzen, 2003). Lathyrus tefennicus an endemic species was found in Tefenni of Burdur province at Turkey and growed in Pinus L. forests. The flowering and fruiting time was between May and July. The colour and size of seeds were varied from dark brown to dark green with the rough-surfaced and 2.9-3.8 $\times 4.8-6 \mathrm{~mm}$ with a $1.5-3.2 \mathrm{~mm}$ long hilum, recpectively (Genç \& Şahin, 2011). Furthermore, Lathyrus egirdiricus an endemic species was found about $3 \mathrm{~km}$ far from Eğirdir of Isparta province at Turkey. The colour of its flower was light purple and bloom in between May and July. However, the colour of seed was varied from light brown to dark brown with rough-surfaced. The size of seed is 6-8 per legume, $2 \times 4 \mathrm{~mm}$, hilum $0.5-1 \mathrm{~mm}$ (Genç \& Şahin, 2008). The accuracy of the method was performed by using certified reference material (EnviroMAT Contaminated Soil) at $95 \%$ confidence level with good agreement. It was thought that the data obtained in this study could be used for plant taxonomy based on chemotaxonomics.

\section{Material and Methods}

\subsection{Material}

The seeds of Lathyrus tefennicus and Lathyrus egirdiricus were collected from natural habitat in Tefenni (Burdur) and Eğirdir (Isparta) in May 2016.

\subsection{Reagents and apparatus}

All reagents were of analytical reagent grade. The stock solutions $(1000 \mathrm{mg} / \mathrm{L})$ of $\mathrm{Cd}, \mathrm{Cr}, \mathrm{Ni}$, $\mathrm{Cu}, \mathrm{Mn}, \mathrm{Zn}, \mathrm{Fe}, \mathrm{Ca}, \mathrm{Mg}, \mathrm{Na}$ and $\mathrm{K}$ were prepared from $\mathrm{Cd}\left(\mathrm{NO}_{3}\right)_{2} \cdot 4 \mathrm{H}_{2} \mathrm{O}$ (Aldrich), $\mathrm{Cr}\left(\mathrm{NO}_{3}\right)_{3} \cdot 9 \mathrm{H}_{2} \mathrm{O}$ (Merck), $\mathrm{Ni}\left(\mathrm{NO}_{3}\right)_{2} \cdot 6 \mathrm{H}_{2} \mathrm{O}$ (Merck), $\mathrm{CuSO}_{4} \cdot 5 \mathrm{H}_{2} \mathrm{O}$ (Sigma-Aldrich), $\mathrm{MnSO}_{4} \cdot \mathrm{H}_{2} \mathrm{O}$ (Sigma-Aldrich), $\mathrm{ZnCI}_{2}$ (Merck), $\mathrm{FeCI}_{3} \cdot 6 \mathrm{H}_{2} \mathrm{O}$ (Merck), $\mathrm{CaCI}_{2} \cdot 2 \mathrm{H}_{2} \mathrm{O}$ (Sigma-Aldrich) $\mathrm{Mg}\left(\mathrm{NO}_{3}\right)_{2} \cdot 6 \mathrm{H}_{2} \mathrm{O}$ (Riedel-de Haën), NaCI (Sigma-Aldrich) and $\mathrm{KNO}_{3}$ (Merck), respectively. 18.2 M $\mathrm{M.cm}$ deionized water (PURIS, Expe-up) was used for all 
experimental studies. The concentrated $\mathrm{HNO}_{3}, \mathrm{HCI}$, and $\mathrm{HF}$ solutions used for the digestion step were supplied from Merck, Riedel de Haën and Merck, respectively. A flame atomic absorption spectrometry (ATI Unicam 939 model) was used for determination of all metals. The operating conditions in determination step were shown in Table 1.

The microwave digestion system (CEM, Mars 6 240/50 model) was used to digest both the seeds and certified reference material (EnviroMAT Contaminated Soil). The digestion conditions for the seeds and certified reference material were given in Table 2.

\subsection{Digestion procedure}

The seeds were first washed with distilled water and then dried at the room temperature. Afterwards, they were homogenized using a porcelain agate and stored in polyethylene bottles until experiment. During the digestion, $1.0 \mathrm{~g}$ of seed samples and $0.2 \mathrm{~g}$ of the certified reference material (EnviroMAT Contaminated Soil) were introduced into a Teflon vessel. Then, $3 \mathrm{~mL}$ of concentrated $\mathrm{HNO}_{3}, 3 \mathrm{~mL}$ of concentrated $\mathrm{H}_{2} \mathrm{O}_{2}, 1 \mathrm{~mL}$ of concentrated $\mathrm{HCIO}_{4}$ and $3 \mathrm{~mL}$ of deionized water were added on all samples, respectively. After digestion procedure given in Table 2, the samples were transferred into polyethylene bottles and kept in the refrigerator until analysis.

\section{Result and Discussion}

\subsection{Concentrations of metals in the seeds}

The concentrations of some metals such as $\mathrm{Cd}, \mathrm{Cr}, \mathrm{Ni}, \mathrm{Cu}, \mathrm{Mn}, \mathrm{Zn}, \mathrm{Fe}, \mathrm{Ca}, \mathrm{Mg}, \mathrm{Na}$ and $\mathrm{K}$ were determined using by FAAS after digestion procedure. The standard solutions were prepared between 0.2 and $10 \mathrm{mg} / \mathrm{L}$ depending on metals and the absorbance values of the metals were measured in both standard and sample solutions using the calibration method. The linear equations of calibration graphs for all metals were given in Table 3. The concentrations of metals in the Lathyrus tefennicus and Lathyrus egirdiricus were calculated by using these linear equations depending on metals.

Cd in plants decreased the plant cultivation and microorganism variety (Sobariu et al., 2017). The Cr(III) was an essential metal and played important roles in the biological systems. However, the $\mathrm{Cr}(\mathrm{VI})$ was toxic for plants, animals and human beings. In general, $\mathrm{Cr}$ was transferred from the soil to plant (Sobariu et al., 2017). Ni was a serious pollutant due to burn of coal and petroleum and using of excessive fertilizer. The Ni concentration in the plant was increased with increasing $\mathrm{Ni}$ concentration in the soil. Its concentration in the plants was affected by the climate and soil $\mathrm{pH}$. The excessive amount of $\mathrm{Ni}$ slowed down the plant growth (Kabala \& Singh, 2001). Cu was an essential metal for all creatures. $\mathrm{Cu}$ was attended in some important biological mechanisms such as carbohydrate and lipid metabolism. However, the excessive amount of $\mathrm{Cu}$ could cause to harmful effects on the blood and kidney (Xiang et al., 2010). Mn was another essential metal and played an important role in the growth of plants. Because of this, the Mn salt was added to the soil (Lemos et al., 2009). Zn was toxic for plant growth when it was taken at higher than essential amount. In addition to this, the adsorption of $\mathrm{Cd}$ by the plant was diminished in the soil because of $\mathrm{Zn}$ (Pehlivan et al., 2008). Fe was essential for all creatures and it had significant functions for some 
processes such as DNA synthesis, oxygen and electron transport. The high amount of Fe could cause the tissue damage (Maiga et al., 2005). Ca was an essential metal for plant growth and development. Additionally, Ca played the crucial role in regulation of membrane permeability, stabilization of tissues and quality of plants (Tuna \& Özer, 2005). Mg was accepted as the iron of the plant world. Similar to the Fe-hemoglobin relationship in humans, Mg entered the chlorophyll structure in plants (Solak Görmüş \& Ergene, 2004). Na played an important role to adjust the blood volume, pressure, the osmotic balance and the $\mathrm{pH}$ value in the body. However, higher amounts of Na may cause to hypertension, stroke, stomach cancer, osteoporosis and kidney diseases (Hwang et al., 2017). K played some important roles such as regulate of plant water potential, form and transport of proteins, carbohydrates, fats and convert of amino acids into proteins. $\mathrm{K}$ was the most important element affecting the quality parameters of the plant such as color, odor, aroma, durability, hardness, resistance against diseases and storage period (Kacar \& Katkat, 1998).

The concentration of metals in both Lathyrus tefennicus and Lathyrus egirdiricus and other plants in the literature were compared and the results were given in Table 4.

\subsection{Method validation}

The accuracy of the proposed method developed was checked by applying certified reference material (EnviroMAT Contaminated Soil) for $\mathrm{Cu}$ determination. The $\mathrm{Cu}$ amount was found as $174 \mathrm{mg} / \mathrm{kg}$ in the certified reference material and there was a good agreement between found and certified values at $95 \%$ confidence level with $-8.9 \%$ relative error.

\section{Conclusion}

To the best of our knowledge, this was the first study to determine metal composition of new Lathyrus tefennicus and Lathyrus egirdiricus seeds. The amounts of $\mathrm{Cd}, \mathrm{Cr}, \mathrm{Ni}, \mathrm{Cu}, \mathrm{Mn}, \mathrm{Zn}$, $\mathrm{Fe}, \mathrm{Ca}, \mathrm{Mg}, \mathrm{Na}$ and $\mathrm{K}$ in the seeds were determined using by FAAS after digestion step with microwave oven. Significant toxic metals such as $\mathrm{Cd}, \mathrm{Cr}$ and $\mathrm{Ni}$ were not found in seeds. $\mathrm{Cu}$ were determined as $4.71 \pm 0.09 \mathrm{mg} / \mathrm{kg}$ and $3.74 \pm 0.09 \mathrm{mg} / \mathrm{kg}$ in Lathyrus tefennicus and Lathyrus egirdiricus, respectively. Mn values were found as $9.65 \pm 0.40 \mathrm{mg} / \mathrm{kg}$ in Lathyrus tefennicus and $11.0 \pm 0.28 \mathrm{mg} / \mathrm{kg}$ in Lathyrus egirdiricus. Zn were found as $25.0 \pm 0.32 \mathrm{mg} / \mathrm{kg}$ and $42.0 \pm 1.3 \mathrm{mg} / \mathrm{kg}$ in Lathyrus tefennicus and Lathyrus egirdiricus, respectively. The amounts of Fe were found as $66.0 \pm 3.0 \mathrm{mg} / \mathrm{kg}$ and $51.0 \pm 3.0 \mathrm{mg} / \mathrm{kg}$ in Lathyrus tefennicus and Lathyrus egirdiricus seeds, respectively. The amounts of Ca were identified as $760 \pm 62.0$ $\mathrm{mg} / \mathrm{kg}$ and $1343 \pm 98.0 \mathrm{mg} / \mathrm{kg}$ in Lathyrus tefennicus and Lathyrus egirdiricus seeds, respectively. The $\mathrm{Mg}$ amounts were determined as $1374 \pm 38.0 \mathrm{mg} / \mathrm{kg}$ and $1026 \pm 82.0 \mathrm{mg} / \mathrm{kg}$ in Lathyrus tefennicus and Lathyrus egirdiricus seeds, respectively. The concentrations of $\mathrm{Na}$ were found as $6650 \pm 59.0 \mathrm{mg} / \mathrm{kg}$ and $4967 \pm 251 \mathrm{mg} / \mathrm{kg}$ in Lathyrus tefennicus and Lathyrus egirdiricus seeds, respectively. The amounts of $\mathrm{K}$ in Lathyrus tefennicus and Lathyrus egirdiricus seeds were found as $5306 \pm 202 \mathrm{mg} / \mathrm{kg}$ and $5919 \pm 210 \mathrm{mg} / \mathrm{kg}$, respectively. Furthermore, the accuracy of method was confirmed by the analysis of certified reference material (EnviroMAT Contaminated Soil). According to results, it was decided that 2 different endemic Lathyrus taxa were also different for the chemical compositions based on t-test calculations at $95 \%$ confidence level. Additionally, the presence of elements at different 
concentrations in the both endemic Lathyrus species could be used in the plant taxonomy. We thought that these results could provide a basis for studies on taxa.

\section{References}

Allkin, R., Goyder, D. J., Bisby, F. A., \& White, R. J. (1986). Names and Synonyms of Species and Subspecies in the Vicieae. Issue 3. Vicieae Database Project, University of Southampton, Southampton, UK.

Amari, T., Ghnaya, T., \& Abdelly, C. (2017). Nickel, cadmium and lead phytotoxicity and potential of halophytic plants in heavy metal extraction. South African Journal of Botany, 111, 99-110.

Chaves, E. S., Santos, E. J., Araujo, R. G. O., Oliveira, J. V., Frescura, V. L. A., \& Curtius, A. J. (2010). Metals and phosphorus determination in vegetable seeds used in the production of biodiesel by ICP OES and ICP-MS. Microchemical Journal, 96, 71-76.

Davis, P. H., Mill, R. R., \& Tan, K. (1988). Flora of Turkey and the East Aegean Islands, Vol. 10 (Supplement). Edinburgh University Press, pp. 125-126.

Davis, P. H. (1970). Flora of Turkey and the East Aegean Islands, Vol. 3. Edinburgh University Press, pp. 328-369.

Elik, A., Altunay, N., \& Gürkan, R. (2017). Microextraction and preconcentration of Mn and $\mathrm{Cd}$ from vegetables, grains and nuts prior to their determination by flame atomic absorption spectrometry using room temperature ionic liquid. Journal of Molecular Liquids, 247, 262-268.

Filipiak-Szok, A., Kurzawa, M., \& Szłyk, E. (2015). Determination of toxic metals by ICP-MS in Asiatic and European medicinal plants and dietary supplements. Journal of Trace Elements in Medicine and Biology, 30, 54-58.

Genç, H., \& Şahin, A. (2001). Batı Akdeniz ve Güney Ege Bölgesinde yetişen Bazı Lathyrus L. türleri üzerinde sitotaksonomik araştırmalar III. S.D.Ü. Fen Bilimleri Dergisi, 5(1), 98-112.

Genç, H., \& Şahin, A. (2008). A new species of Lathyrus L. (section Cicercula; Fabaceae) from Turkey. Botanical Journal of the Linnean Society, 158, 301-305.

Genç, H., \& Şahin, A. (2011). A new species of Lathyrus L. (Fabaceae) from Turkey. Journal of Systematics and Evolution, 49(5), 505-508.

Genç, H. (2009). Lathyrus nivalis subsp. sahinii subsp. nov. (Sect. Platystylis, Leguminosae) from Turkey. Nordic Journal of Botany, 27, 402-404.

Güner, A., Özhatay, N., Ekim, T., \& Başer, K. H. C. (2000). Flora of Turkey and the East Aegean Islands, Vol. 11 (Supplement 2). Edinburgh University Press, pp.92-94.

Güneş, F., \& Çırpıc1, A. H. (2012). A new record for the of Turkey: Lathyrus atropatanus (Leguminosae). Turkish Journal of Botany, 36, 425. 


\section{Macrothink}

Journal of Biology and Life Science ISSN 2157-6076 2018, Vol. 9, No. 2

Güneş, F. (2014). A new species of Lathyrus (Fabaceae) from Turkey. Pensee Journal, 76(3), 339-350.

Heredia, J. Z., Cina, M., Savio, M., Gil, R. A., \& Camiña, J. M. (2016). Ultrasound-assisted pretreatment for multielement determination in maize seed samples by microwave plasma atomic emission spectrometry (MPAES). Microchemical Journal, 129, 78-82.

Hwang, J., Kim, J., Moon, H., Yang, J., \& Kim, M. (2017). Determination of sodium contents in traditional fermented foods in Korea. Journal of Food Composition and Analysis, 56, $110-114$.

Kabala, C., \& Singh, B. R. (2001). Fraction and mobility of copper, lead and zinc in soil profiles in the vicinity of a copper smelter. Journal of Environmental Quality, 30, 485-492.

Kacar, B., \& Katkat, V. (1998). Bitki besleme. Uludağ Üniversitesi güçlendirme vakfı yayını, yayin no: 127, 595 s, Bursa.

Klamt, A., \& Schifino-Wittmann, M. T. (2000). Karyotype morphology and evolution in some Lathyrus (Fabaceae) species of southern Brazil. Genetics and Molecular Biology, 23(2), 463-467.

Lajayer, B. A., Ghorbanpour, M., \& Nikabadi, S. (2017). Heavy metals in contaminated environment: Destiny of secondary metabolite biosynthesis, oxidative status and phytoextraction in medicinal plants. Ecotoxicology and Environmental Safety, 145, 377-390.

Lemos, V. A., Novaes, C. G., \& Bezerra, M. A. (2009). An automated preconcentration system for the determination of manganese in food samples. Journal of Food Composition and Analysis, 22, 337-342.

Liu, F., Liu, W., Ding, W., Lv, G., \& Zhou, X. (2014). Trace Elements Analysis by ICP-OES after Microwave Digestion of Medicago sativa L. Seeds from Different Locations in Xinjiang, China. Asian Journal of Chemistry, 26, 3522-3526.

Maiga, A., Diallo, D., Bye, R., \& Paulsen, B. S. (2005). Determination of some toxic and essential metal 1ons in medicinal and edible plants from Mali. Journal of Agricultural and Food Chemistry, 53, 2316-2321.

Mohamed, B. A., Ellis, N., Kim, C. S., \& Bi, X. (2017). The role of tailored biochar in increasing plant growth, and reducing bioavailability, phytotoxicity, and uptake of heavy metals in contaminated soil. Environmental Pollution, 230, 329-338.

Pehlivan, E., Arslan, G., Gode, F., Altun, T., \& Özcan, M. M. (2008). Determination of some inorganic metals in edible vegetable oils by inductively coupled plasma atomic emission spectroscopy (ICP-AES). Grasas y Aceites, 59(3), 239-244.

Santos Júnior, A. F., Matos, R. A., Andrade, E. M. J., Santos, W. N. L., Magalhães, H. I. F., Costa, F. N., \& Korn, M. G. A. (2017). Multielement Determination of Macro and Micro Contents in Medicinal Plants and Phytomedicines from Brazil by ICP OES. Journal of The Brazilian Chemical Society, 28, 376-384. 


\section{Macrothink}

Sobariu, D. L., Fertu, D. I. T., Diaconu, M., Pavel, L. V., Hlihor, R. M., Drâgoi, E. N., Curteanu, S., Lenz, M., Corvini, P. F. X., \& Gavrilescu, M. (2017). Rhizo bacteria and plant symbiosis in heavy metal uptake and its implications for soil bioremediation. New Biotechnology, 39, 125-134.

Solak Görmüş, Z. I., \& Ergene, N. (2004). Magnezyumun klinik önemi, Genel Tıp Dergisi, 14(2), 69-75.

Tuna, A. L., \& Özer, Ö. (2005). Farklı Kalsiyum Bileşiklerinin Karpuz (Citrullus lanatus) Bitkisinde Verim, Beslenme ve Bazı Kalite Özellikleri Üzerine Etkisi, Ege Üniversitesi Ziraat Fakültesi Dergisi, 42(1), 203-212.

Tutin, T. G., Heywood, V. H., Burges, N. A., Moore, D. M., Valentine, D. H., Walters, S. M., \& Webb, D. A. (1968). Flora Europaea, Vol. 2. Cambridge University Press, pp. 136-143.

Tüzen, M. (2003). Determination of heavy metals in soil, mushroom and plant samples by atomic absorption spectrometry. Microchemical Journal, 74, 289-297.

Xiang, G., Zhang, Y., Jiang, X., He, L., Fan, L., \& Zhao, W. (2010). Determination of trace copper in food samples by flame atomic absorption spectrometry after solid phase extraction on modified soybean hull. Journal of Hazardous Materials, 179, 521-525.

Yamamoto, K., Fujiwara, T., \& Blumenreich, I. D. (1984). Karyotypes and Morphological Characteristics of Some Species in the Lathyrus L.. Japan. J. Breed., 34, 273-284.

Zhang, L., Nie, X. Y., \& Le, T. (2017). Rapid determination of 15 metallic elements in 2 kinds of coix seeds by inductively coupled plasma-mass spectrometry after closed-vessel microwave digestion. Journal of Food Process Engineering, 40(5), 1-6. 
Table 1. The operating conditions of FAAS for metals

\begin{tabular}{cccc}
\hline Metals & Wavelength $(\mathbf{n m})$ & Slit width $(\mathbf{n m})$ & Lamb current (mA) \\
\hline $\mathrm{Cd}$ & 228.8 & 0.5 & 8.0 \\
\hline $\mathrm{Cr}$ & 357.9 & 0.5 & 12.0 \\
\hline $\mathrm{Ni}$ & 232 & 0.2 & 15.0 \\
\hline $\mathrm{Cu}$ & 324.8 & 0.5 & 5.0 \\
\hline $\mathrm{Mn}$ & 279.5 & 0.2 & 12.0 \\
\hline $\mathrm{Zn}$ & 213.9 & 0.5 & 10.0 \\
\hline $\mathrm{Fe}$ & 248.3 & 0.2 & 15.0 \\
\hline $\mathrm{Ca}$ & 422.7 & 0.5 & 6.0 \\
\hline $\mathrm{Mg}$ & 285.2 & 0.5 & 4.0 \\
\hline $\mathrm{Na}$ & 589 & 0.2 & 8.0 \\
\hline $\mathrm{K}$ & 766.5 & 0.5 & 8.0 \\
\hline
\end{tabular}

Table 2. Microwave digestion operating conditions for seeds

\begin{tabular}{cc}
\hline Steps & Time $(\mathbf{m i n})$ \\
\hline Heating process & 15 \\
\hline Thawing process $\left(200^{\circ} \mathrm{C}\right)$ & 15 \\
\hline Cooling process & 15 \\
\hline
\end{tabular}


Table 3. The linear equations for calibration graphs

\begin{tabular}{ccc}
\hline Metals & Lineer Equation & $\mathbf{R}^{2}$ \\
\hline $\mathrm{Cd}$ & $\mathrm{y}=0.078 \mathrm{x}+0.004$ & 0.999 \\
\hline $\mathrm{Cr}$ & $\mathrm{y}=0.016 \mathrm{x}+0.000$ & 1.000 \\
\hline $\mathrm{Ni}$ & $\mathrm{y}=0.021 \mathrm{x}+0.001$ & 0.999 \\
\hline $\mathrm{Cu}$ & $\mathrm{y}=0.054 \mathrm{x}-0.002$ & 0.999 \\
\hline $\mathrm{Mn}$ & $\mathrm{y}=0.065 \mathrm{x}+0.001$ & 0.999 \\
\hline $\mathrm{Zn}$ & $\mathrm{y}=0.099 \mathrm{x}-0.002$ & 0.999 \\
\hline $\mathrm{Fe}$ & $\mathrm{y}=0.017 \mathrm{x}-0.006$ & 0.996 \\
\hline $\mathrm{Ca}$ & $\mathrm{y}=0.033 \mathrm{x}-0.002$ & 0.997 \\
\hline $\mathrm{Mg}$ & $\mathrm{y}=0.047 \mathrm{x}+0.009$ & 0.993 \\
\hline $\mathrm{Na}$ & $\mathrm{y}=11.80 \mathrm{x}+6.482$ & 0.996 \\
\hline $\mathrm{K}$ & $\mathrm{y}=4.375 \mathrm{x}+2.038$ & 0.998 \\
\hline
\end{tabular}


Table 4. Concentration of metals in Lathyrus tefennicus and Lathyrus egirdiricus, $\bar{x} \pm \frac{t s}{\sqrt{N}}$ and other plants in the literature (N:11; N.D ${ }^{*}$ Not detected)

\begin{tabular}{|c|c|c|c|}
\hline Metals (mg/kg) & $\begin{array}{c}\text { Found in Lathyrus } \\
\text { tefennicus }\end{array}$ & $\begin{array}{c}\text { Found in Lathyrus } \\
\text { egirdiricus }\end{array}$ & Literature \\
\hline \multirow{3}{*}{$\mathrm{Cd}$} & \multirow{3}{*}{ N.D. } & \multirow{3}{*}{ N.D. } & $\begin{array}{c}0.17 \pm 0.01 \mathrm{mg} / \mathrm{kg} \text { (in smaller coix seeds) } \\
\text { (Zhang et al., 2017) }\end{array}$ \\
\hline & & & \\
\hline & & & $\begin{array}{c}0.025 \pm 2.56 \text { and } 0.038 \pm 9.63 \mu \mathrm{g} / \mathrm{g} \text { (in } \\
\text { Medicago sativa } \mathrm{L} . \text { seeds) (Liu et al., 2014) }\end{array}$ \\
\hline \multirow[t]{2}{*}{$\mathrm{Cr}$} & \multirow[t]{2}{*}{ N.D. } & \multirow[t]{2}{*}{ N.D. } & $\begin{array}{c}0.18 \pm 0.01 \mathrm{mg} / \mathrm{kg} \text { (in smaller coix seeds) and } \\
0.02 \pm 0.00 \mathrm{mg} / \mathrm{kg} \text { (in bigger coix seeds) } \\
\text { (Zhang et al., 2017) }\end{array}$ \\
\hline & & & $\begin{array}{l}29.69 \pm 1.20 \text { and } 43.88 \pm 1.83 \mu \mathrm{g} / \mathrm{g} \text { (in } \\
\text { Medicago sativa L. seeds) (Liu et al., 2014) }\end{array}$ \\
\hline \multirow[t]{2}{*}{$\mathrm{Ni}$} & \multirow[t]{2}{*}{ N.D. } & \multirow[t]{2}{*}{ N.D. } & $\begin{array}{c}0.79 \pm 0.03 \mathrm{mg} / \mathrm{kg} \text { (in smaller coix seeds) and } \\
0.16 \pm 0.01 \mathrm{mg} / \mathrm{kg} \text { (in bigger coix seed) } \\
\text { (Zhang et al., 2017) }\end{array}$ \\
\hline & & & $\begin{array}{c}3.8 \pm 0.3 \text { and } 5.0 \pm 0.8 \mu \mathrm{g} / \mathrm{g} \text { (in maize seeds) } \\
\text { (Heredia et al., 2016) }\end{array}$ \\
\hline \multirow{3}{*}{$\mathrm{Cu}$} & \multirow{3}{*}{$4.7 \pm 0.1$} & \multirow{3}{*}{$3.7 \pm 0.1$} & $\begin{array}{c}2.88 \pm 0.14 \mathrm{mg} / \mathrm{kg} \text { (in smaller coix seeds) and } \\
1.65 \pm 0.05 \mathrm{mg} / \mathrm{kg} \text { (in bigger coix seed) } \\
\text { (Zhang et al., 2017) }\end{array}$ \\
\hline & & & $\begin{array}{l}21.44 \pm 0.11 \text { and } 102.24 \pm 1.15 \mu \mathrm{g} / \mathrm{g} \text { (in } \\
\text { Medicago sativa } \mathrm{L} . \text { seeds) (Liu et al., 2014) }\end{array}$ \\
\hline & & & $\begin{array}{c}18.2 \pm 1.3 \text { and } 52.8 \pm 18.5 \mu \mathrm{g} / \mathrm{g} \text { (in maize } \\
\text { seeds) (Heredia et al., 2016) }\end{array}$ \\
\hline \multirow{3}{*}{$\mathrm{Mn}$} & \multirow{3}{*}{$9.7 \pm 0.4$} & \multirow{3}{*}{$11.0 \pm 0.3$} & $\begin{array}{c}22.70 \pm 0.87 \mathrm{mg} / \mathrm{kg} \text { (in smaller coix seeds) } \\
\text { and } 19.66 \pm 0.75 \mathrm{mg} / \mathrm{kg} \text { (in bigger coix seed) } \\
\text { (Zhang et al., 2017) }\end{array}$ \\
\hline & & & $\begin{array}{l}19.68 \pm 1.33 \text { and } 28.34 \pm 0.80 \mu \mathrm{g} / \mathrm{g} \text { (in } \\
\text { Medicago sativa L. seeds) (Liu et al., 2014) }\end{array}$ \\
\hline & & & $\begin{array}{c}5.5 \pm 0.7 \text { and } 17.4 \pm 7.9 \mu \mathrm{g} / \mathrm{g} \text { (in maize seeds) } \\
\text { (Heredia et al., 2016) }\end{array}$ \\
\hline \multirow{3}{*}{$\mathrm{Zn}$} & \multirow{3}{*}{$25.0 \pm 0.3$} & \multirow{3}{*}{$42.0 \pm 1.3$} & $\begin{array}{c}22.72 \pm 1.01 \mathrm{mg} / \mathrm{kg} \text { in smaller coix seeds) and } \\
23.88 \pm 1.02 \mathrm{mg} / \mathrm{kg} \text { (in bigger coix seed) } \\
\text { (Zhang et al., 2017) }\end{array}$ \\
\hline & & & $\begin{array}{l}27.44 \pm 0.72 \text { and } 57.01 \pm 0.67 \mu \mathrm{g} / \mathrm{g} \text { (in } \\
\text { Medicago sativa L. seeds) (Liu et al., 2014) }\end{array}$ \\
\hline & & & $\begin{array}{c}13.1 \pm 1.7 \text { and } 25.9 \pm 7.9 \mu \mathrm{g} / \mathrm{g} \text { (in maize seeds) } \\
\text { (Heredia et al., 2016) }\end{array}$ \\
\hline $\mathrm{Fe}$ & $66.0 \pm 3.0$ & $51.0 \pm 3.0$ & $\begin{array}{c}34.86 \pm 0.87 \mathrm{mg} / \mathrm{kg} \text { in smaller coix seeds) and } \\
47.21 \pm 0.74 \mathrm{mg} / \mathrm{kg} \text { (in bigger coix seed) }\end{array}$ \\
\hline
\end{tabular}


(Zhang et al., 2017)

$125.94 \pm 0.36$ and $528.81 \pm 2.13 \mu \mathrm{g} / \mathrm{g}$ (in

Medicago sativa L. seeds) (Liu et al., 2014)

$14.0 \pm 0.9$ and $84.9 \pm 10.7 \mu \mathrm{g} / \mathrm{g}$ (in maize seeds) (Heredia et al., 2016)

$92.54 \pm 3.61 \mathrm{mg} / \mathrm{kg}$ in smaller coix seeds) and

$96.74 \pm 3.12 \mathrm{mg} / \mathrm{kg}$ (in bigger coix seed)

(Zhang et al., 2017)

$\begin{array}{lll}\mathrm{Ca} & 760.0 \pm 62.0 & 1343.0 \pm 98.0\end{array}$

$2298.75 \pm 0.39$ and $3611.25 \pm 0.68 \mu \mathrm{g} / \mathrm{g}$ (in

Medicago sativa L. seeds) (Liu et al., 2014)

$5.61 \pm 2.62 \mu \mathrm{g} / \mathrm{g}$ (in maize seeds) (Heredia et al., 2016)

$1687.46 \pm 34.77 \mathrm{mg} / \mathrm{kg}$ in smaller coix seeds) and $1624.31 \pm 62.32 \mathrm{mg} / \mathrm{kg}$ (in bigger coix seed) (Zhang et al., 2017)

$\begin{array}{lll}M g & 1374.0 \pm 38.0 & 1026.0 \pm 82.0\end{array}$

$1886.25 \pm 0.58$ and $2148.75 \pm 1.41 \mu \mathrm{g} / \mathrm{g}$ (in

Medicago sativa L. seeds) (Liu et al., 2014)

$437 \pm 29$ and $993 \pm 99 \mu \mathrm{g} / \mathrm{g}$ (in maize seeds) (Heredia et al., 2016)

$37.63 \pm 8.53 \mu \mathrm{g} / \mathrm{g}$ (in cotton seed), $25.44 \pm 7.66 \mu \mathrm{g} / \mathrm{g}$ (in sunflower seed), $23.70 \pm 7.60 \mu \mathrm{g} / \mathrm{g}$ (in tung seed), $36.40 \pm 3.97$ $\mathrm{Na} \quad 6650.0 \pm 59.0 \quad 4967.0 \pm 251.0 \quad \mu \mathrm{g} / \mathrm{g}$ (in soybean seed), $175 \pm 20 \mu \mathrm{g} / \mathrm{g}$ (in curcas bean seed), $86 \pm 5 \mu \mathrm{g} / \mathrm{g}$ (in fodder turnip seed) and $32.93 \pm 8.08 \mu \mathrm{g} / \mathrm{g}$ (in castor bean seed) (Chaves et al., 2010).

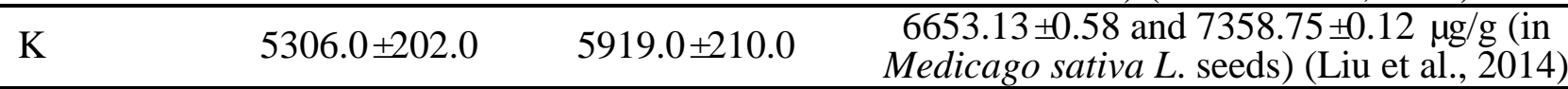

\section{Copyright Disclaimer}

Copyright for this article is retained by the author(s), with first publication rights granted to the journal.

This is an open-access article distributed under the terms and conditions of the Creative Commons Attribution license (http://creativecommons.org/licenses/by/3.0/). 